\title{
OPEN Author Correction: Whole rumen metagenome sequencing allows classifying and predicting feed efficiency and intake levels in cattle
}

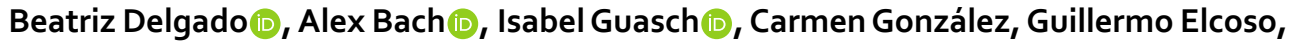 \\ Jennie E. Pryce \& Oscar Gonzalez-Recio 1
}

Correction to: Scientific Reports https://doi.org/10.1038/s41598-018-36673-w, published online 09 January 2019

This Article contains a typographical error in the Methods section under subheading 'Metagenome ensemble' where,

"The annotation was performed with options -compliant -centre UoN -norrna -notrna -metagenome, and a bioproject was submitted to NCBI database with number PRJNA423102."

should read:

"The annotation was performed with options -compliant -centre UoN -norrna -notrna -metagenome, and a bioproject was submitted to NCBI database with number PRJNA423103.”

(c) (i) Open Access This article is licensed under a Creative Commons Attribution 4.0 International License, which permits use, sharing, adaptation, distribution and reproduction in any medium or format, as long as you give appropriate credit to the original author(s) and the source, provide a link to the Creative Commons license, and indicate if changes were made. The images or other third party material in this article are included in the article's Creative Commons license, unless indicated otherwise in a credit line to the material. If material is not included in the article's Creative Commons license and your intended use is not permitted by statutory regulation or exceeds the permitted use, you will need to obtain permission directly from the copyright holder. To view a copy of this license, visit http://creativecommons.org/licenses/by/4.0/.

(C) The Author(s) 2020 